\title{
Translating Character's Traits: a Case of Gadis Pantai and Its English Translation
}

\author{
Deta Maria Sri Darta ${ }^{1}$, MR Nababan ${ }^{2}$, Riyadi Santosa ${ }^{3}$, Djatmika $^{4}$ \\ \{detamaria@student.uns.ac.id¹; amantaradja@yahoo.com²; riyadisantosa@staff.uns.ac.id³; \\ djatmika@uns.ac.id $\left.{ }^{4}\right\}$ \\ Cultural Science Faculty, Universitas Sebelas Maret, Surakarta ${ }^{1,2,3}$
}

\begin{abstract}
Literary translation is a never-ending topic to discuss, especially when it comes to the subject of translation. Tanslation is a way for a non-English literary text to be acknowledged as a part of world literature. In translating a literary text, a translator must understand that it has some elements, some structures that she/he needs to follow in order to convey the meaning from source text to target text. One of the important elements in literary text is characters' traits. The author, in her attempt to develop the characters' traits along the story line, must have some agenda to convey to the readers, thus the translated version must also carry the same purpose. This paper scrutinizes the traits of characters in Gadis Pantai and how they are translated into English in The Girl from the Coast, using the help of one type of appraisal, affect. Affect was chosen because it is the prominent type of appraisal found in the novel. The data were taken in form of words, phrases, and clauses that are used by the author to depict the character's feelings. They were compared to the data found in the target text to see how they were translated into English. This paper also discusses some possible accurate renderings, shifting in the subtype of affect, and loosing message. The result of this paper aims to raise awareness from translators, especially literary translators, in translating characters' traits.
\end{abstract}

Keywords: literary translation, traits, affect

\section{Introduction}

The era of fourt industrial revolution (or industri 4.0) has enabled technology to accelerate the distribution of literary texts. This contributes to the growth of world literature. To be reckoned worldwide, i.e. as a part of world literature, a non-English literary text should be well translated into English. Through translation, Indonesian literary text, for example, will receive attention from the readers all over the world. This is very beneficial both for the work and for the author. This is in line with Damrosch opinion that world literature consists of translated literary text (2003: 281). However, it is not easy to perform a well-done job when it comes to translating literary text. It is belevied that the success of a literary text sometimes depends on its translation. Moreover, Bandel in her book says that the translated texts are kinds of reproduction of the texts that should maintain all elements from the original texts (2013: 252). Meaning that translated literary texts should serve as reproductions of the original texts which carry the literary elements that formed the texts. The problem with literary translation is the freedom that the translators might feel when doing their job of translating literary texts. This 
feeling emerges since literary texts are work of creativity, thus people might think that the translators have as much freedom as they want; which actually is not true.

There are some elements of literature that the translators need to understand in order to do their job well. One of the elements to be considered is the portrayal of the characters' traits. The author of a literary text should depict the characters as natural as posible as if they are living in a real world. There are some traits assigned to the characters that help the readers to understand the whole story, to get the message that the author wants to convey. If a character is not depicted as portrayed by the author in the original text, we can say that the characteristics of that character changes. If affects to the identity of that particular character change, it might also change the character development aimed by the author. This difference causes unequal dramatic effects if the readers read both versions. As Nida \& Taber (1974: 1) believe that the Target Text readers ${ }^{6}$ reaction is the aim of translation, thus the success of translation also depends on the equivalent readers' reaction of the two versions.

It is true that translation without shifting is hard to do, but the shifts done are for the sake of achievin the aim of translation itself. We should bear in mind that the shifts are made because of the different cultures and grammatical structures own by the two languages (source and target languages). Therefore, the shifts should be done in a careful manner since too much deviation will make the result no longer a translation, but an adaptation.

Translating literary texts require the translators to understand the text as a whole. The translator is the first reader of the target text, she/he should interpret the text first before translating it. If she/he misinterprets the source text, most likely the translated version is shifted. This paper would like to scrutinize the traits of one of the main characters in Gadis Pantai (i.e. Gadis Pantai) written by Pramoedya Ananta Toer and how those traits are translated into English in The Girl from the Coast, using the help of one type of appraisal, affect.

\section{Understanding Characterization and Affect}

\subsection{Character and Characterization}

Different from the term 'character' which refers to the 'persona' in the story, character or characteristic means the traits that are interpreted by readers about the 'persona' (Nurgiyantoro, 2015: 248). Thus, there are two meanings of the term character, one is as a 'persona' in the story and second is as traits of that particular 'persona'. While characterization means how the 'persona' is portrayed and given clues about so that readers can understand. The dictionary meaning of 'persona' according to Meriam Webster online dictionary means a character assumed by an author in a written work. It also means the aspect of someone's character that is presented to or perceived by others.

In literature there are two ways done by the author to depict the traits of a character: directly and indirectly, or in Abrams terms telling and showing (1999: 34). The traits include the character's physical appearance, psychological traits (emotion, feeling), and sociological traits.

\subsection{Affect}

Dealing with affect, we need to understand its root. It is one type of a framework to analyze the use of language to evaluate or widely known as appraisal (White, 2011: 14). Affect is one part of appraisal which describes or evaluates feeling, both positive and negative, direct and indirect (White, 2011: 16). Text shows positive or negative evaluation through emotional 
response of speakers. For example: "I am disappointed and ashamed that two of our most admired and respected sportsmen could behave in such manner" (White, 2011: 16). In that sentence the underlined words show the speaker's evaluation about others, which we call affect.

Affect is divided into four: dis/inclination, un/happiness, in/security dan dis/satisfaction. Below are tables that consist of the types and example of affect taken from Martin \& Rose (2007: $65-66)$

Table 1. Kinds of Affect

(modified from Martin \& Rose, 2007: 65 - 66)

\begin{tabular}{|c|c|c|}
\hline KINDS OF AFFECT & & SURGE (of behaviour) \\
\hline \multirow[b]{2}{*}{ Dis/inclination } & Fear & $\begin{array}{l}\text { tremble } \\
\text { shudder } \\
\text { cower }\end{array}$ \\
\hline & Desire & $\begin{array}{l}\text { suggest } \\
\text { request } \\
\text { implore }\end{array}$ \\
\hline \multirow{4}{*}{ In/security } & $\begin{array}{l}\text { insecurity: } \\
\text { disquiet }\end{array}$ & $\begin{array}{l}\text { restless } \\
\text { twitching } \\
\text { shaking }\end{array}$ \\
\hline & $\begin{array}{l}\text { insecurity: } \\
\text { surprise }\end{array}$ & $\begin{array}{l}\text { start } \\
\text { cry out } \\
\text { faint }\end{array}$ \\
\hline & $\begin{array}{l}\text { security: } \\
\text { confidence }\end{array}$ & $\begin{array}{l}\text { declare } \\
\text { assert } \\
\text { proclaim }\end{array}$ \\
\hline & security: trust & $\begin{array}{l}\text { delegate } \\
\text { commit } \\
\text { entrust }\end{array}$ \\
\hline \multirow{4}{*}{ Dis/satisfaction } & $\begin{array}{l}\text { disatisfaction: } \\
\text { ennui }\end{array}$ & $\begin{array}{l}\text { figget } \\
\text { yawn } \\
\text { tune out }\end{array}$ \\
\hline & $\begin{array}{l}\text { disatisfaction: } \\
\text { displeasure }\end{array}$ & $\begin{array}{l}\text { caution } \\
\text { scold } \\
\text { castigate }\end{array}$ \\
\hline & $\begin{array}{l}\text { satisfaction: } \\
\text { interest }\end{array}$ & $\begin{array}{l}\text { attentive } \\
\text { busy } \\
\text { flat out }\end{array}$ \\
\hline & $\begin{array}{l}\text { satisfaction: } \\
\text { admiration }\end{array}$ & $\begin{array}{l}\text { pat on the back } \\
\text { compliment } \\
\text { reward }\end{array}$ \\
\hline \multirow[b]{2}{*}{ Un/happiness } & $\begin{array}{l}\text { unhappiness: } \\
\text { misery } \\
\text { [mood: 'in me'] }\end{array}$ & $\begin{array}{l}\text { wimper } \\
\text { cry } \\
\text { wail }\end{array}$ \\
\hline & $\begin{array}{l}\text { unhappiness: } \\
\text { anthipathy } \\
\text { [directed feeling: } \\
\text { 'at you'] }\end{array}$ & $\begin{array}{l}\text { rubbish } \\
\text { abuse } \\
\text { revile }\end{array}$ \\
\hline
\end{tabular}




\begin{tabular}{|l|l|l|}
\hline & happiness: cheer & $\begin{array}{l}\text { chuckle } \\
\text { laugh } \\
\text { rejoice }\end{array}$ \\
\cline { 2 - 3 } & $\begin{array}{l}\text { happiness: } \\
\text { affection }\end{array}$ & $\begin{array}{l}\text { shake hands } \\
\text { hug } \\
\text { cuddle }\end{array}$ \\
\hline
\end{tabular}

\subsection{Relation between characterization and affect}

Knowing the meaning of character and characterization as well as affect, we can draw a line on the relation between them. Since we have learnt that affect is a way to evaluate someone's feeling or emotion, we can use it to interpret the character's feeling about someone or something. Words, phrases, and clauses spoken by the character or other characters about that specific character are taken and analyze using affect to have a conclusion about the character's psychological traits.

\section{Methodology}

The study used qualitative method. In line with Creswell (2007: 16), a research in translation has plural and heterogenous reality. The data were in the form of words, phrases, clauses taken from the novel and were only those related to character of Gadis Pantai's feeling, both directly and indirectly. The data then were analyzed using the type of affect, to understand how the character negotiates her feeling. After analyzing the affects found, the character's traits were concluded. Finally, after finding the traits, the next step was comparing the affects found in ST to the ones found in TT. This step was done to see how they were translated, to check whether the translator successfully conveyed the traits or not.

\section{Finding and Discussion}

\subsection{Indonesian version of Gadis Pantai}

The analysis of affect in Gadis Pantai is done to find out the traits of the main character, Gadis Pantai. Since the title of the novel and the name of the character being analyzed is similar; if it is writing in italic (Gadis Pantai), it refers to the title of the novel; when it is written as Gadis Pantai, it refers to the name of the main character. However, to make it simpler, in the discussion and finding, when it refers to the name of the character, it is abbreviated into GP. After gathering the words, phrases, and clauses related to the way GP expressed her feelings, 157 affects are found. Those are from all four types of affect. The figure below shows the distributions. 


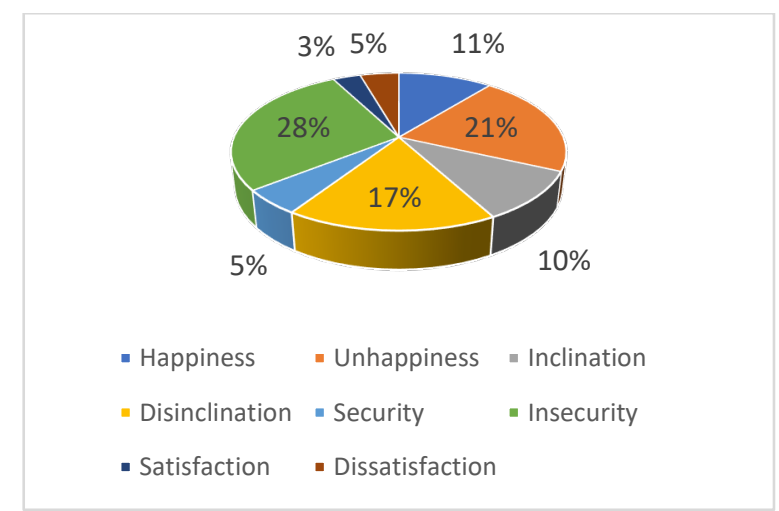

Figure 1. Affect of GP

The figure above shows that the three prominent types of affect found is insecurity, unhappiness, and disinclination. Those three types are the negative ones. However, GP also felt happy, satisfied, and secure too. She was depicted as 'lifelike' as human being with all complex aspect of feelings found in her traits. The following paragraphs will discuss each type of affect found.

At the beginning of the story, GP was portrayed as a girl who grew up in fisherman village. She only knew things about coast and the life of fisherman; she had never known any life outside her village. When she was about to marry Bendoro (a rich man from the city), she did not know what to do. She felt sad marrying someone she had never known before, but she had no power to fight against her condition. She feared of things she had never known before. However, on the contrary, her youth in fisherman village was full of happiness. It can be seen form the expression (the expression within the brackets is the English version):

Hari demi hari batinnya diisi derai ombak...

(The girl's life, her soul, was each day filled by the sound of the waves ...)

The above expression is included as happiness: cheer (disposition). It shows that she felt happy of her everyday life, as if she did not need other thing than what she had. It is supported with the next happiness: cheer expression found:

Ia tak pernah merasa miskin dalam empatbelas tahun ini.

(She had never ever thought of herself as being poor...)

On the contrary, her new life with Bendoro was full of fear, worry and insecurity. Not knowing the new life she had to face, she felt that she was about to lose her entire life. This is supported by the finding of an affect under category unhappiness: misery (surge). The exact expression is as follow:

Ia tak tahu apa yang di hadapannya.

Ia hanya tahu: ia kehilangan seluruh hidupnya.

(The girl didn't understand. Neither did she know what lay ahead.

All she knew was that she had just lost her entire world.) 
Those two expressions show that GP felt miserable as she said that she had lost her entire world she had back in fisherman village.

Being out from her comfort zone (the fisherman village) scared her. She was afraid of the uncertainty that she faced. She was not prepared to face the new life outside the fisherman village, where she felt lonely due to the silence in Bendoro's big house. The examples of the expression of fear and insecure:

Kadang dalam ketakutan ia bertanya: mengapa tak boleh tinggal di mana ia suka, di antara orang-orang tersayang dan tercinta, di bumi pantai dan ombaknya yang amis. (Why couldn't she live where she wanted to, she asked herself with fear and apprehension, among the people she cared for and loved, in her seaside world of pounding waves?)

Gadis Pantai jadi bimbang, takut, curiga.

(The change confused the girl, made her feel frightened and apprehensive.)

The first sentence shows her expression of disinclination: fear (disposition), while the second shows a more complex feeling, a kind of combination of fear and insecurity. The words "bimbang" (confused) and "curiga" (apprehensive) indicate her insecurity (disquiet disposition), while the word "takut" (frightened) shows her feeling of disinclination (fear disposition). However, GP was just a young girl, who could easily change her mood. Indeed, she felt a tremendous sadness, but she also found an ease over her unhappy feeling. When she saw several goods that she had never had before, she felt comfortable with the soft sandals and bed she had never used before.

Namun ia rasai tubuhnya nikmat tenggelam dalam kasur yang begitu lunak seperti lumpur hangat.

(..., she had come to enjoy the sensation of her body sinking into a soft mattress.)

That expression shows that GP also felt happy. The sentence (source text) is categorized as satisfaction: admiration (disposition).

The next chapter of her life as Bendoro's wife was full of the feeling of fear. She was afraid of Bendoro, her husband, someone that she had never known before. She felt insecure since she had to learn new things that she had never done before. She used to live without strict rules, but now as Bendoro's wife, a well-known and wealthy person, she had to follow some orders, which was too scary for her. Loosing her freedom made her feel insecure. The two expressions below are examples among the negative feeling she felt during her life as Bendoro's wife.

Kembali Gadis Pantai jadi bisu ketakutan. Ia rasai nafasnya tersumbat. (Again, the girl was dumbstruck with fear; she felt as if she couldn't breathe.)

Otaknya terpilin-pilin...

(The girl's mind reeled.)

The first two sentences which were translated into one sentence in English are the example of GP's evaluation on her feeling of disinclination: fear (disposition); represented by the word "ketakutan" (fear) and insecurity: disquiet (surge); represented by the phrase "nafasnya 
tersumbat" (couldn't breathe). The next example is categorized under the type of dissatisfaction: ennui (disposition).

After collecting all data on her affect, GP's traits especially her psychological ones can be interpreted. She used to be a happy girl who was satisfied with her condition as the girl who lived in the coast (fisherman village). She was forced to move out of her comfort zone as she was about to marry a wealthy person from the city, Bendoro. Her life changing made her experience new feelings. She was portrayed of having more negative feelings than she had before she moved to the city. She was not used to silence, so she was afraid, unhappy and insecure about her existence. Not being able to get what she used to have also contributed to her negative feelings. Although fancy goods that she had never had before gave a little distraction from her sadness, still those negative feelings were dominant.

\subsection{English version of Gadis Pantai}

After finding the GP's feelings that were expressed in forms of affect, the comparison to the English version was made to see if the affects were successfully translated or not. Almost all of the affects found were translated successfully into its English version. The translator found his way to deliver the affects into English, though he had to add some explanation. Of course, some shifts were found. In the case of GP's traits, the affects found vary and were many. Thus, the deletion and shift that happened, if they were not thoroughly examined, do not change a major part of GP's traits. However, the changes were quite risky if the readers compare the two versions. The shifts found can be categorized into the change of type of affect, deletion of the affect used, and additional context.

The first type was the change of affect type. The word choice in translating the words or phrases indicated the certain type of affect make that type of affect changed into the other type. Although in this study, some of them were still under category of affect, but still it created changes. The following is the example of the change from satisfaction: admiration (disposition) into happiness: affection (disposition):

Tapi selop rumput itu memang menyenangkan tungkainya.

(Silently, though, she did admit she liked the feel of the grass sandals on her feet.)

The original sentence contains a word "menyenangkan" (pleasing) that is categorized as affect under type of satisfaction: admiration (disposition), while the English version it was replaced by the word "liked" which is included as happiness: affection (disposition).

Another example under this changing was from disinclination: fear (disposition) into insecurity: disquiet (disposition). Similar to the previous example, when one word in original sentence was replaced with another word or even a phrase that was not categorized under the same type of affect, the change occurred.

Gadis Pantai jadi ketakutan

(The girl suddenly felt rush of panic)

In the above example the word "ketakutan" (afraid) was replaced by the phrase "rush of panic" which is indicated insecurity: disquiet (disposition).

The next change was deletion. Although this kind of changes was found only a few, but they contributed on the lost of some evidences of a certain trait. In literary analysis, finding the sufficient evidence to support an interpretation was badly needed. When several sentences were collected under the same category of interpretation, they served as strong proofs that literary 
critics needed to support their arguments. So, not only does a deletion erase one kind of traits, the action also reduce the existence of strong evidence needed. For example, in the original text there was a sentence saying: "Ia merasa asing." (she felt strange) which showed the GP did not feel like home. The phrase "merasa asing" (feeling strange) represented the feeling of insecurity: disquiet (disposition).

Tidak! Bendoro tidak membawa wanita utama baru, ia menjerit dalam hati. Tidak! Tidak mungkin.

(Had he brought a new woman into the house? She asked herself silently. No, he couldn't have.)

Scrutinized under the same category of deletion, there were some findings show that the appraisal (affect) was replaced by a non-appraisal one. The above example, the original sentence contained a phrase "menjerit dalam hati" (screaming in her heart) which means she wanted to scream, to speak out her feeling, but she could not do it, then she did that silently. It was not only to ask herself a question, but more to express her feeling of fear. Thus, we lose one proof of disinclination: fear (disposition).

The last category was the additional context. Although this category did not really harm the type of affect found, it reduced the dramatic effect. For example:

Ia tak berani.

(She didn't have the nerve to drink.)

The translator gave the context of the fear experienced by GP by adding the context to it. This category of change was the only category that was found harmless to the depiction of GP. However, the translator should be very careful in adding the context, so that the readers of the target text did not misunderstand the meaning that the author tried to convey.

From the discussion above can be sum up that over all the depictions of GP in the original text compared to the ones in the target text were not sharply different. Still the minor changes found contributed to the reduction of evidence or proof needed by the reader to interpret the characteristic of GP, especially through one type of appraisal, affect. Understanding appraisal was proven to be a handful skill that the translators might have in translating literary text. This discussion also demonstrated how the study of linguistics and literature collided and helped one another. The idea of separating the two studies seemed to be outdated. Thanks to the study of translation that served as a bridge between the two -used to be opposing- studies. Moreover, in the era of revolution industry 4.0, where technology created an ease for the distribution of literary texts, as well as the convenient of translating texts using aids, it would be such a shame if the fast-growing world literature was not followed by a thoughtful action to preserve the language in which literature and translation are dealing with. As the branch of study to scrutinize language, linguistics serves as a helpful tool to transfer the message from the original literary texts to their translated versions. Tracing our path in discussing the case of the affect translation in Gadis Pantai, the translators might have to ponder on understanding the elements of literary text more. 


\section{Conclusion}

After analyzing Gadis Pantai's related expression of affect, some traits can be concluded concerning her psychological depictions. Gadis Pantai (GP) was portrayed as a happy and contented girl until she was brought to town to marry Bendoro, a wealthy man who liked to marry young girls. Her feeling was changed into a more negative one. She was depicted as an unhappy girl who was surrounded by insecurity and fear. It was proven by the three dominant negative affects found. In the English version, some changes occurred. There are three types of changes found: the shift from one type of affect to another, the deletion including the changes from affect (appraisal in general) into non appraisal, and the last one is additional context provided.

The changes and deletion make the traits of Gadis Pantai (GP) shifted. Although in the case of Gadis Pantai the changes were not dominant, these kinds of shifting can be considered risky. If the translator understands the idea of interpreting the character's traits using appraisal, for example, she/he might have a better version of translation. Appraisal helps the translator to decide the unit of translation before s/he begins to translate character's traits. Since the deleted and shifted affect after being translated, it might result on the different traits that is being portrayed by the author. Thus, translating a literary text is as risky as translating other types of text.

\section{References}

Abrams, M. H. A glossary of literary terms. Boston, Massachusetts: Heinle \& Heinle; 1999.

Baker, M. In other words: a coursebook of translation. London and New York: Routledge; 2018.

Baldick, C. The concise oxford dictionary of literary term. Oxford: Oxford Paperback Reference: 2001.

Bandel, K. Sastra nasionalisme pascakolinialitas. Yogyakarta: Pustaha Hariara: 2013.

Bassnett, S. Translation studies. New York: Routledge; 2005.

Reflections on translation. UK: Multilingual Matters; 2011.

Bell, R. T. Translation and translating: theory and practice. London: Longman; 1993.

Creswell, J. W. Qualitative inquiry \& research design. California: Sage Publication: 2007.

Culpeper, J. Language and characterisation: people in plays and other texts. Singapura: Pearson Education Asia Pte. Ltd.; 2001.

Damrosch, D. What is world literature? New Jersey: Princeton University Press; 2003.

Hatim, B and J. Munday. Translation: an advanced resource book. New York: Routledge. 
Martin, J.R \& David Rose. Working with discourse. London: Continuum; 2007.

Martin, J.R \& P.R.R. White. The language of evaluation “appraisal in English.” New York: Palgrave Macmillan; 2005.

Molina, L \& Hurtado Albir, A. "Translation techniques revisited: a dynamic and functionalist approach". Meta. 2002; 47(4): 498-512.

Nurgiyantoro, Burhan. Teori pengkajian fiksi. Yogyakarta: UGM Press; 2018.

Santosa, R. Metode penelitian kualitatif kebahasaan. Surakarta: UNS Press; 2017. 